\title{
Effect of New Media on Political Participation in the Border Area of the Republic of Indonesia - The Democratic Republic of East Timor
}

\author{
Kennorton Hutasoit ${ }^{1}$, Henni Gusfa ${ }^{2}$, Ahmad Mulyana ${ }^{3}$ \\ \{kennortonhs@gmail.com ${ }^{1}$, henni.gusfa@gmail.com ${ }^{2}$, ahmadmulyana09@gmail.com ${ }^{3}$ \} \\ Universitas Mercu Buana, Indonesia ${ }^{1,2,3}$
}

\begin{abstract}
Indonesia held the Legislative and Presidential Elections simultaneously on April 17, 2019. In these elections' candidates and the success team actively used new media to influence voters. This research was conducted to find out how much influence the new media has on political participation in the 2019 elections, especially in Belu Regency as the border region of Indonesia-Timor Leste. The researchers previously examined the effect of the new media on the election of governors whose locations were in urban areas. In contrast to this study conducted in simultaneous elections located in rural areas in Belu Regency. This Research conducted in April 2019 with 282 respondents of beginner's voter in Belu Regency. The independent variables examined in this study were affect new media $(\mathrm{X})$ and dependent variables of voter participation $(\mathrm{Y})$. The theories used in this study are stimulus response theory, magic bullet theory, and political participation concept. Based on linear regression analysis, the variable $\mathrm{X}$ has a positive effect on the variable Y. However, this effect is included in the weak category with a correlation rate of 31.5 percent.
\end{abstract}

Keywords: Effect Media, New Media, Political Participation, Border Area.

\section{Introduction}

Indonesia held the Legislative and Presidential Elections simultaneously on April 17, 2019. In these elections candidates and the success team actively used new media to influence voters. This research was conducted to find out how much influence the new media has on political participation in the 2019 elections, especially in Belu Regency as the border region of Indonesia - Timor Leste. The researchers previously examined the effect of the new media on the election of governors whose locations were in urban areas. In contrast to this study conducted in simultaneous elections located in rural areas in Belu Regency.

In previous studies, new media influenced voters in the election of governors in East Java and North Sumatra. Two pairs of candidates in the East Java governor election used the new media in the process of their political campaign with the different way. The results of the analysis of the uploads displayed and the results of the vote at the election stage indicate that natural and consistent uploads can attract public sympathy as the Khofifah-Emil pair did [1]. In the North Sumatra 2018 governor election, beginners have great potential to exercise their right to vote, although the duration and frequency of accessing social media with political content is lacking, but they also take the time to read good profiles of political party profiles and become 
followers, so they feel confident they will participate in the political process by using their suffrage [2].

In Belu Regency, East Nusa Tenggara, it is different from East Java and North Sumatra. The number of new media users in Belu Regency is far below the number of new media users nationally. In Indonesia, according to the Indonesian Internet Service Providers (APJII), new media users in March 2019 there were 171.17 million people or 64.8 percent. In Belu Regency, there is no recent data about new media users. In 2014 according to LPP RRI, the number of new media users in Belu Regency was 24.45 percent. The influence of new media on voters is likely to differ depending on the condition of the population, especially on access to the new media itself.

The study was conducted in the border region with the consideration that the environmental conditions of the border region may affect the political participation of the community, especially beginners voters. These beginners voters used their right to vote for the first time in the 2019 election.

The number of millennials include beginners voters in the 2019 general elections, according to kpu.go.id reached $40 \%$ of the 180 million registered voters on the Permanent Voter List. This number is phenomenal and this is the first time the majority of voters throughout the election. In Belu Regency the number of beginners voters was 3.5 percent of 126,727 total voters.

Political participation in the border region from election to election has fluctuated. Based on data from kpu.go.id, the level of voter participation in Belu Regency, East Nusa Tenggara Province in the 2009 Presidential Election was $70.98 \%$, down to $59.45 \%$ in the 2014 presidential election, and rising to $71.89 \%$ in the 2019 presidential election. This research will answer the question what is the effect of new media on political participation in the RI-Timor Leste border region.

\section{Theoretical Framework}

Social media that is widely used by the public today is part of new media [3]. Here are seven social media with the most users in the world: 1) Google+ with a total of 1.6 billion users; 2 ) Facebook with 1.28 billion users; 3) Twitter with 0.645 billion users; 4) Instagram with 415 million users; 6 LinkedIn with 300 million users; Pinterest with 70 million users; and Path with 30 million users. Especially in Indonesia, the most widely used social media are Facebook and Twitter [4].

In Indonesia, according to the Indonesian Internet Service Providers (APJII) internet users in March 2019 there were 171.17 million people or 64.8 percent of the total 264 million population of Indonesia. The number of internet users is up 10.12 percent from the previous year.

The internet has given birth to digital communication. The basic concept in digital communication consists of cyberspace, virtual reality, virtual communities, chatt rooms, MUD, and Bot, interactivity, and multimedia. William Gibson makes the definition of cyberspace is a reality that is connected globally supported by computers, computer access, multidimensional, artificial, or virtual in Severin [5]. The key characteristic that distinguishes old media from new media from a user perspective is: 1) interactivity); 2) Social presence or sociability; 3) media richness; 4) autonomy; 5) playfulness: 5) privacy: 6) personalization [6]. 
In this study, the Stimulus - Response theory is used as a grand theory to examine the effect of new media on political participation. Stimulus - Response Theory was developed from Psychology in the 1930s [7]. Stimulus - Response Theory can be described as follows:

$$
\text { Stimulus } \rightarrow \text { Interpretation } \rightarrow \text { Response [8]. }
$$

The main elements of stimulus response are: message (stimulus), a receiver or receiver (organism), and effect (response) [9]. The stimulus-response model is as follows:

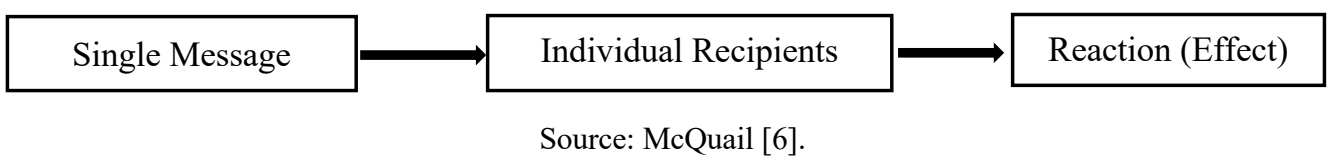

The middle theory in this research is magic bullet theory. This theory is basically a simple learning principle, in this case the effect is a reaction to a certain stimulus-response. This explains a close relationship between media messages and audience reaction [10]. Theory is known as the syringe model or bullet model which says that newspaper coverage and support for political candidates will also determine the election results [11].

The effect of magic bullet theory media emerged during and after World War I. In the form of experiments, research with this model was conducted by Hovlan to examine the influence of allied propaganda in changing attitudes [12].

Magic bullet theory includes communication variables including communicator credibility, audience characteristics, and message content. The next variable is an effect variable consisting of cognitive, affective, and conative effects [13].

Media exposure according to Rosengren (1974) in Rachmat can be operationalized into the amount of time used in various types of media, media content consumed, and various relationships between individual media consumers with consumed media content or with the whole media [13]. Meanwhile, according to Sari media exposure can be operationalized into the type of media used by the frequency of exposure, and duration of use [13].

The hypodermic media effect emphasizes what the media does to the audience. In a quantitative approach, research is conducted by measuring media exposure [14]. The frequency of exposure to new media is categorized in one week to be: 1) Very often if there are 8 times of exposure; 2) Often if exposed as much as 6-7 times; 3) Not often if exposed as much as 4-5 times; 4) Very often not if exposed as much as 2-3 times; Whereas for the duration or duration of individuals with new media exposure categorized as follows: 1) Very long if exposed to new media 46-60 minutes; 2) Long if exposed to new media 31-45 minutes; 3) Not long if new media exposure is $16-30$ minutes; 4) Very shortly if exposure to new media is 1-15 minutes [15]

In this study the frequency category is divided into three categories, namely: (1) There is no exposure to new media at all; (2) exposure to new media less than once a week; (3) exposure to new media at least once a week [16].

\subsection{Concept of Political Participation}

Political participation of citizens is the participation of citizens in giving their voting rights in elections and the participation of citizens in determining political policies including influencing government policies. The dimensions of citizen political participation consist of: 1) political trust; 2) participation in (political) associations; 3) participation in (social) associations; 
4) campaign activity; 5) political knowledge; 6) political efficacy; 7) social trust; 8) political discussion; and 9) political understanding [17].

In this research the concept of political participation taken from Jimenez are political discussion and political understanding. Other forms of political participation are taken from the concept of political participation in general election from Nimmo [18] as follows: 1) Identification with political parties; 2) Registration to vote; 3) Voting in general elections. 4) Taking part in the campaign [18].

\subsection{Border Region of the Republic of Indonesia - Timor Leste}

The media accessed by residents in border area based on 2014 LPP RRI research are television $81.36 \%$, radio $82.36 \%$, online media $24.45 \%$, newspapers $23.45 \%$, magazines $6.21 \%$, tabloids $2.0 \%$ and other media $0.80 \%$. Meanwhile, the population of the border region that accesses media from neighboring countries is $29.06 \%$ and the remaining $70.94 \%$ has never accessed it. The types of media of the most widely accessed neighboring countries are television $40.00 \%$ and radio $39.31 \%$, and online media $16.55 \%$. While the neighboring newspapers that are read by border communities in Indonesia are only $1.38 \%$, magazines $0.69 \%$ and others $1.38 \%$.

Belu Regency, is a Regency which borders directly with the Democratic Republic of Timor Leste (RDTL). RDTL was once part of Indonesia which is a province of East Timor. Therefore, Belu Regency residents and RDTL residents who are separated by the state are still in one culture because of ethical similarities such as the ethnic Kemak, Marae, Tetun and Belu. Media access in Belu Regency is generally the same as in other border areas. But it is different in terms of information needs due to differences in the characteristics of the population of each region. Atambua residents who are the capital of Belu Regency as much as $60 \%$ need national information, as many as $43 \%$ need information on regional events, $23 \%$ need information on Indonesia's progress in the eyes of the world, $20 \%$ of the history of Indonesia's struggle, and cultural information from other regions $13 \%$ [19].

\subsection{Framework}

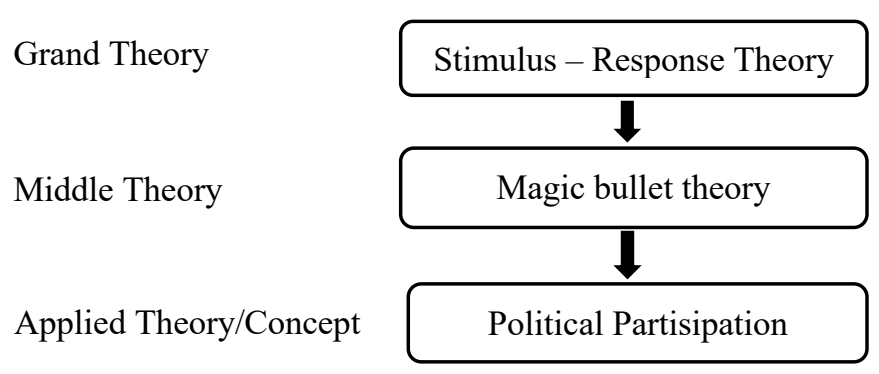

\subsection{Hypothesis}

If the more frequent and longer use of new media, that the level of political participation of beginner's voters will be increasingly in the border region of Indonesia - Timor Leste. 


\section{Method}

The paradigm of this research is positivistic. This study uses a quantitative approach. The cornerstone of thinking quantitative approach is the philosophy of positivism which uses data to measure the relationships between variables [20]. The independent variables examined in this study were effect new media (X) and dependent variables of voter participation (Y) [21]. This Research conducted in April 2019 with 282 respondent of beginners voter in Belu Regency.

\section{Results and Discussion}

This study found that out of 282 respondents in Belu District, there were $9.93 \%$ of beginner voters aged 15 to 16 who were married. The percentage of the age of first marriage at 15 years to 16 years is close to the percentage of the age of first marriage in Belu Regency recorded by Central Bureau of Statistics (BPS) in 2017 which is $10.34 \%$.

This study found that the most widely used social media in the RI - Timor Leste border region was Facebook with a percentage of $60.28 \%$ of the total 282 respondents. The second most used social media is Instagram $20.21 \%$. While Twitter is in third place is news portal / or other online media by $14.18 \%$ and fourth is Twitter with a percentage of $13.82 \%$.

This study found the majority of respondent namely 112 respondents or $39.80 \%$ of the total 282 respondents had frequency of exposure to New Media 2-3 times each day. The second highest frequency of watching New Media exposure is 8 times or more every day ie 102 respondents or $36.25 \%$ of the total 282 respondents. While those that have never been hit by new media are $0 \%$ or none.

For the duration of exposure to new media the majority of respondents namely 121 respondents or $42.90 \%$ of the total 282 respondents had a duration of exposure to new media for 1-15 minutes each time using new media. The duration of the second most new media exposure is $46-60$ minutes each time using new media that is 77 respondents or $31.11 \%$ of the total 282 respondents.

This study found that the majority of respondents namely 239 respondents or $84.75 \%$ of the total 282 respondents participated in discussions about politics, elections, presidential candidates, political parties, and candidates. As many as 230 respondents or $81.56 \%$ of the total 282 respondents knew and had closeness or attachment to certain political parties. As many as 251 respondents or $89.00 \%$ of the 282 respondents checked their names in the provisional voter list (DPS) or permanent voter list (DPT) either manually coming to the kelurahan or online through the KPU website. A total of 102 respondents or $36.17 \%$ of the 282 respondents who attended the campaign were public meetings or joined campaign meetings, helping the success teams of presidential candidates, political parties, or certain candidates either directly by inviting others, or by installing campaign props or by using social media.

All respondents were beginner voters who came to the polling station to vote or vote for the presidential-vice presidential candidates, political parties, or candidates. However, of the respondents who came to cast their ballots, 97 respondents or $34.39 \%$ of 282 respondents stated that information from television and / or new media (social media) helped determine their choices. 
Table 1. Normal distribution test with Kolmogorov Smirnov

\begin{tabular}{|c|l|c|c|}
\hline No. & \multicolumn{1}{|c|}{ Variable } & Asymp. Sig. (2-tailed) & $\alpha=0,05$ \\
\hline 1. & Exposed to New Media (X2) & 0,213 & 0,05 \\
\hline 2. & Political Participation (Y) & 0,140 & 0,05 \\
\hline
\end{tabular}

Source: Data processed by researchers.

Based on the testing rules that if the probability (sig.) $>0.05$ then Ho is accepted, it means that the data is normally distributed and if the probability (sig.) $<0.05$, then Ho is rejected, it means the data is not normally distributed. In the Asymp column. Sig (2-tailed) shows that the probability value (sig.) Of all variables namely new media (X) is 0.213 and political participation (Y) is 0.140 greater than $\alpha=0.05$. This shows that the data of all variables are normally distributed.

Table 2. Simple Linear Regression Test

\begin{tabular}{|c|c|c|c|c|c|c|c|c|c|}
\hline \multicolumn{10}{|c|}{ Model Summary $^{\mathbf{b}}$} \\
\hline \multirow[b]{2}{*}{ Model } & \multirow[b]{2}{*}{$\mathrm{R}$} & \multirow[b]{2}{*}{$\begin{array}{c}\mathrm{R} \\
\text { Square }\end{array}$} & \multirow[b]{2}{*}{$\begin{array}{l}\text { Adjusted } \\
\text { R Square }\end{array}$} & \multirow{2}{*}{$\begin{array}{l}\text { Std. Error } \\
\text { of the } \\
\text { Estimate }\end{array}$} & \multicolumn{5}{|c|}{ Change Statistics } \\
\hline & & & & & $\begin{array}{l}\text { R Square } \\
\text { Change }\end{array}$ & $\begin{array}{c}\mathrm{F} \\
\text { Change }\end{array}$ & df1 & df2 & $\begin{array}{c}\text { Sig. F } \\
\text { Change }\end{array}$ \\
\hline 1 & $.315^{\mathrm{a}}$ & 0.099 & 0.096 & 3.250 & 0.099 & 30.925 & 1 & 280 & 0.000 \\
\hline \multicolumn{10}{|c|}{ a. Predictors: (Constant), X } \\
\hline b. Depe & ident V & riable: $Y$ & & & & & & & \\
\hline
\end{tabular}

Source: Data processed by researchers.

Based on the table above the coefficient $\mathrm{R}^{2}$ is 0.099 and the adjusted $\mathrm{R}^{2}$ is 0.096 . That is, the level of correlation of new media $(\mathrm{X})$ on the voter participation variable $(\mathrm{Y})$ is very weak. The table above shows that the correlation between the variables of new media exposure (X) and political participation (Y) obtained a value of $\mathrm{r}=0.315$ which indicates a weak positive relationship. Based on the above table F-count of new media exposure $(\mathrm{X})=30,925$ is bigger than $\mathrm{t}$ table with the formula: $\mathrm{F}$ table $=\mathrm{t}(\alpha / 2)(\mathrm{n}-1)=\mathrm{t}(0.05 / 2)(282-1)=7,025$. The $\mathrm{t}$ count $\mathrm{X}=30,925>\mathrm{F}$ table $=7,025$ meaning that the influence between the use of social media $(\mathrm{X})$ on the level of political participation (Y) is significant.

Table 3. Description of the Correlation of New Media Exposure

\begin{tabular}{|c|c|c|c|c|c|c|}
\hline \multicolumn{9}{|c|}{ Correlations } \\
\hline \multirow{4}{*}{$\begin{array}{c}\text { Pearson } \\
\text { Correlation }\end{array}$} & $\mathrm{Y}$ & 1.000 & 0.302 & 0.332 & 0.376 & 0.064 \\
\cline { 2 - 7 } & $\mathrm{X} 2$ & 0.302 & 1.000 & 0.898 & 0.889 & 0.632 \\
\cline { 2 - 7 } & $\mathrm{X} 3$ & 0.332 & 0.898 & 1.000 & 0.885 & 0.597 \\
\cline { 2 - 7 } & $\mathrm{X} 4$ & 0.376 & 0.889 & 0.885 & 1.000 & 0.582 \\
\cline { 2 - 7 } & $\mathrm{X} 1$ & 0.064 & 0.632 & 0.597 & 0.582 & 1.000 \\
\hline \multirow{3}{*}{$\begin{array}{c}\text { Sig. (1- } \\
\text { tailed) }\end{array}$} & $\mathrm{Y}$ & & 0.000 & 0.000 & 0.000 & 0.143 \\
\cline { 2 - 7 } & $\mathrm{X} 2$ & 0.000 & & 0.000 & 0.000 & 0.000 \\
\cline { 2 - 7 } & $\mathrm{X} 3$ & 0.000 & 0.000 & & 0.000 & 0.000 \\
\cline { 2 - 7 } & $\mathrm{X} 4$ & 0.000 & 0.000 & 0.000 & & 0.000 \\
\hline \multirow{3}{*}{$\mathrm{X} 1$} & 0.143 & 0.000 & 0.000 & 0.000 & \\
\cline { 2 - 7 } & $\mathrm{Y}$ & 282 & 282 & 282 & 282 & 282 \\
\cline { 2 - 7 } & $\mathrm{X} 2$ & 282 & 282 & 282 & 282 & 282 \\
\hline
\end{tabular}




\begin{tabular}{|l|l|l|l|l|l|l|}
\hline & $\mathrm{X} 4$ & 282 & 282 & 282 & 282 & 282 \\
\cline { 2 - 7 } & $\mathrm{X} 1$ & 282 & 282 & 282 & 282 & 282 \\
\hline
\end{tabular}

Source: Researcher's processed data using SPSS 25.

The table above can be seen X1 numbers of 0.064 , X2 of 0.302 , X3 of 0.332 , and X4 of 0.376 . This shows that the type of new media has a very weak correlation. While the contents of new media, the frequency and duration of exposure to new media have a weak category correlation. This is a simple linear regression model of this research:

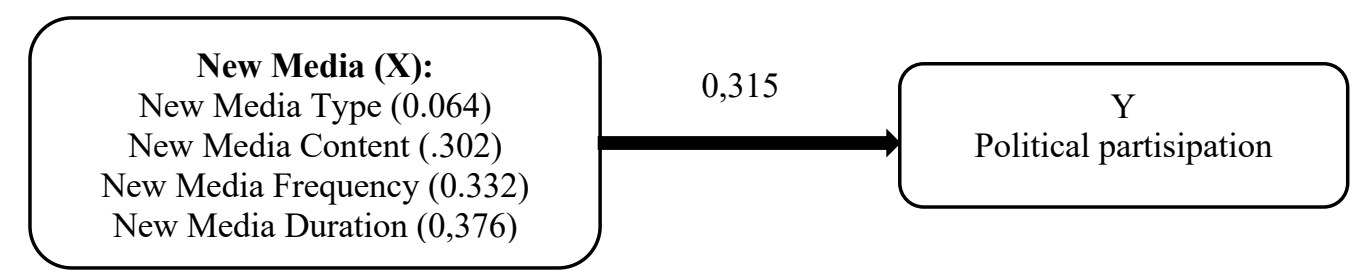

Source: Data processed by researchers.

\subsection{Disscussion}

Based on trials $(\mathrm{R})$, this study found the value of opposition (R) exposure to new media and political participation was 0.315 with a weak participation rate category. Of the considerations of new media exposure of 0.315 , the greatest correlation with political participation is the exposure of new media exposure which is 0.376 with the weak category. The next biggest value is the frequency of exposure to new media that is 0.332 and contents of new media 0.302 . While the smallest correlation value is new media type only 0.064 .

The finding of the weak correlation of exposure to new media with political participation in the border region of Indonesia - Timor Leste can be explained that in the research location there were still 88 respondents or $31.20 \%$ of the total 282 respondents who did not use new media as a source of political and election information. The weak level of correlation between exposure to new media and political participation in this location is likely because there are still many who do not use new media and include not having a smartphone or gadget to access new media. This finding is in line with the 2014 LPP RRI research which found that only $24.45 \%$ of people in the border area were accessing new media.

The weak correlation between new media exposure and political participation can also be explained by the frequency and duration of new media exposure. The majority of respondents namely $39.80 \%$ only had the frequency of exposure to New Media 2-3 times each day and for each time the exposure of new media was only $1-15$ minutes for the majority of $42.90 \%$ of respondents.

The findings of this study are in line with the research of Tri [22] which concluded that the attention and political participation of respondents were classified as low on political matters, only 26 of 95 respondents, although all respondents stated that they had received messages about politics through new media.

Based on the $\mathrm{F}$ test conducted to measure the effect of new media exposure linear regression on political participation, it was found that the calculated $\mathrm{F}$ value was 30.925 well above $\mathrm{F}$ table $=7$. This means that the influence of new media exposure was significant on political participation in the border region of Indonesia - Timor Leste.

When viewed from the $\mathrm{R}$ test the category of level of correlation is weak and a significant $\mathrm{F}$ test shows that exposure to new media is significant and has a positive value, but its correlation 
with political participation is still low because its users are still limited. The findings of this study are in line with studies by Kamiloğlu from İstanbul Aydın University, Turkey and Emre Erdoğan, İstanbul Bilgi University, Turkey (2014) who found that with increasing intensity of Facebook use, the tendency to actively participate also increased. In this study also found that demographic and socioeconomic variables significantly influence the dimensions of active participation. Parental education showing higher socioeconomic status is statistically significant.

When referring to Kamiloğlu [23], the weak correlation between exposure to new media and political participation is related to the demographic and socio-economic factors of adolescents in the RI-Timor Leste border region, namely the level of education is still low and there are still people who cannot read Latin letters around $10.04 \%$.

\section{Conclusion}

After conducting a series of theoretical studies, data analysis, and discussion of research results, the authors conclude the results of the study as follows:

a) Social media is an alternative source of information to find out political and election information in the 2019 Presidential and Legislative Elections in the RI-Timor Leste border region.

b) Based on simple linear regression analysis with correlation test ( $\mathrm{R}$ ) and the significance test $(\mathrm{F})$, this study found that new media exposure positive effect on the political participation of beginner voters in the border region of Indonesia - Timor Leste.

\section{References}

[1] F. Kurniawati, P. Pawito, and W. Muktiyo, "New Media in Political Marketing of Governor Election (Evidence in East Java, Indonesia)," in International Conference on Emerging Media, and Social Science, 2018.

[2] L. Basit, "Social Media and Political Participation of Beginners," in International Conference on Emerging Media, and Social Science, 2018.

[3] W. Wijayanto, "Bourdieu and Media Theory: Explaining Media's Changes and Continuities in The Post Authoritarian Countries," Polit. Indones. Indones. Polit. Sci. Rev., vol. 4, no. 2, pp. 274 300, 2019.

[4] U. Wahid, "Komunikasi Politik: Teori, Konsep, dan Aplikasi Pada Era Media Baru," Bandung, Jawa Barat, Indones. Simbiosa Rekatama Media, 2016.

[5] W. J. Severin and J. W. Tankard Jr, "Teori Komunikasi: Sejarah, Metode, \& Terapan di Dalam Media Massa," Jakarta Prenada Media, Terjemahan, Ed. kelima, 2005.

[6] D. McQuail, “Teori Komunikasi Massa, Edisi 6 Buku 1,” Jakarta: Salemba Humanika, 2011.

[7] S. W. Littlejohn and K. A. Foss, Encyclopedia of communication theory, vol. 1. Sage, 2009.

[8] E. Griffin, “A First Look at Communication Theory McGraw-Hill," New York, NY, 2012.

[9] D. McQuail, A. Dharma, and A. Ram, Teori komunikasi massa: Suatu pengantar. Penerbit Erlangga, 1994.

[10] B. Burhan, "Sosiologi Komunikasi: Teori, Paradigma, dan Diskursus Teknologi Komunikasi di Masyarakat," Jakarta Kencana Prenada Media Gr., 2006.

[11] J. Vivian, "Teori komunikasi massa," Jakarta: Kencana, 2008.

[12] Ardial, Komunikasi Politik. Jakarta: Indeks, 2009.

[13] R. Kriyantono, S. Sos, and M. Si, Teknik praktis riset komunikasi. Prenada Media, 2014. 
[14] G. Branston and R. Stafford, The media student's book. Psychology Press, 2003.

[15] N. P. Wibowo, "Hubungan antara Terpaan Media Tayangan Bima Satria Garuda dengan Perilaku Kekerasan yang dilakukan oleh Anak." Universitas Airlangga, 2014.

[16] R. Das Gupta, I. H. Sajal, M. Hasan, I. Sutradhar, M. R. Haider, and M. Sarker, "Frequency of television viewing and association with overweight and obesity among women of the reproductive age group in Myanmar: results from a nationwide cross-sectional survey," BMJ Open, vol. 9, no. 3, p. e024680, 2019

[17] O. F. D. Jiménez and C. Muniz, "The Effects of Political Communications on Youth Political Engagement in the 2012 Mexican Presidential Election," Rev. Mex. Cienc. Polit. Soc., vol. 62, no. 229, pp. 181-221, 2017.

[18] D. Nimmo, "Komunikasi Politik: Komunikator, Pesan, dan Media, terj," Tjun Surjaman, Cet. VII, Bandung Remaja Rosdakarya, 2011.

[19] S. Santoso, Peran LPP RRI Dalam Mengonstruksi Identitas Nasional Indonesia di Wilayah Perbatasan. Jakarta: Puslitbangdiklat LPP RRI, 2014.

[20] M. Singarimbun and S. Effendi, "Metode penelitian survai," 1982.

[21] I. Ghozali, “Aplikasi analisis multivariete dengan program IBM SPSS 23," 2018.

[22] A. J. Tri, "Dinamika Partisipasi Politik Remaja Melalui Media Sosial,” J. Visi Komun., vol. 13, no. 02, pp. 281-295, 2014.

[23] F. Kamiloğlu and E. Erdoğan, "Effects of social media on civil and political participation and a field of survey over on Facebook," 2012. 